\title{
Research on the Later Influential Factors of College Students' Online Shopping Satisfaction in the Network Building Festival
}

\author{
Tongtong Geng, Yifeng Wang, Zeyuan Li \\ Xidian University, School of Economics and Management, Xi'an, China \\ Email: gtt.jesse@vedasec.com
}

Received 2 December 2015; accepted 26 February 2016; published 1 March 2016

\begin{abstract}
From double eleven Taobao online shopping Carnival to Dianping 517 Foodie Festival, the network building festival has become electricity marketing's new means of innovation, and it has become the external manifestation of the "Internet +" action plan. However, most domestic scholars focus on the shopping experience, the satisfaction of the end of shopping behavior is less. Based on the domestic and foreign research results of customer's online shopping satisfaction, this paper makes a survey on college students who are the research objects, and uses the method of questionnaire survey and SPSS20.0 analysis software to analyze and evaluate the satisfaction degree of customer's online shopping behavior. In this paper, the evaluation index system and model of College Students' later satisfaction degree in shopping carnival are established, and it is help for electricity suppliers to improve customer's online shopping satisfaction in Shopping Festival.
\end{abstract}

\section{Keywords}

Network Building Festival, Customer Behavior, Online Shopping Satisfaction

\section{Introduction}

With the promotion and deepening of the "Internet +" action plan, All kinds of shopping festivals were built by the Internet company have also emerged. We all can see the huge boost consumption of energy that the network shopping festival released. Electricity suppliers through the "Festival" make the promotional activities more interesting, and to stimulate consumer more intense sense of participation. According to data, the sales of Tmall/ Taobao.com's “double eleven” has been rapid growth from 50 million RMB in 2009 to 57100 million RMB in 2014. Recently opened Dianping 517 Foodie Festival started from May 15th 10 points, the turnover break through 200 million during 24 hours, almost 200 million netizen participated in this festival carnival. Therefore, no matter the traditional electricity suppliers or $\mathrm{O} 2 \mathrm{O}$ platform, they all get huge benefits from the "network building festival”. However, after the double eleven online shopping Carnival in 2014, Ma Yun, Alibaba’s president, clarify that he is more concerned about the degree of satisfaction of the consumer in the later stage, and it has become the key to promote the optimization and upgrading of electronic commerce. The college students as 
a special group, is the main force to participate in Online Shopping Festival. Research on the satisfaction degree of Carnival after shopping is valuable to the perfection of the electronic commerce service system.

\section{The Theoretical Foundation and Literature Review}

American scholar Cardozo (1965) first proposed the concept of customer satisfaction, it considers customer satisfaction can encourage customers to repeat purchase [1]. Howard and Sheth (1969) account customer satisfaction is a psychological cognitive process which is paying costs and getting benefits for at the comparison purchase state [2]. Hunt (1977) believes that customer satisfaction is a emotional response that after the customer comparing the paying product or overall rating of service with its values, and is a feeling of consumption during the customer experience [3]. Kotler Philip (1996) believes that "satisfaction refers to the mental state of a person who is formed by a comparison of the efficacy of a product or service that is perceived by the target of his tone" [4]. Consumer satisfaction, also known as customer satisfaction, refers to the customer's satisfaction degree of satisfaction [5]. Lee cited (2007) considers customer satisfaction refers to a mental activity after the product or service offered access to business customers in the spontaneous formation of [6]. Huang Tianlong (2011) refers to the customer that the customer satisfaction before and after purchase, or the entire purchase process expectations and the demand for the product or service purchased, the consumer experience and product performance of cognitive and emotional reactions [7].

Customer satisfaction is a measure of satisfaction level of domestic and foreign scholars are theoretical and empirical research from a specific customer groups launched a series of targeted research, and has made some achievements. Domestic and foreign scholars have attached great importance to enhance the online shopping customer satisfaction, focusing on the key factors of online shopping customer satisfaction influence and made endless assessment model, and initially formed a theoretical framework to guide the practice.

Typically, Hempel (1977) considers that customer satisfaction is determined mainly by the degree of realization of the product's benefits, The higher the degree of the actual performance and the expected degree of consistency, the higher customer satisfaction [8]. Engel (1993) considered that customer satisfaction is the comparison of the expectation and effect. If the effect is higher than that of consumption, the customer is satisfied [9]. Lacobucci and Ostrom (1995) believe that customer satisfaction is a relative concept, which requires customers to compare the costs and benefits of labor and the quality and benefits obtained from every purchase [10]. Szymanski and HASS (2000) first proposed the concept of satisfaction in e-commerce and construct the conceptual model of the retail network customer's satisfaction. He confirmed that convenience, commodity information, website design and financial security have a significant positive impact on customer satisfaction, which is the most obvious effect of convenience on customer satisfaction [11]. Kim and Lim (2001) found that the factors such as entertainment, convenience, information quality, reliability, speed and so on. The information quality, entertainment, reliability and speed were related to customer satisfaction [12]. Billy Bai and Rob Law (2008) put forward the concept model of the quality of the website. The empirical research shows that the quality of the website can significantly influence customer satisfaction. Meanwhile, customer satisfaction has positive effect on purchase intention [13]. Alam, Syed Shah and Yasin, Norjaya Mohd (2010) uses 4 key dimensions to evaluate online shopping satisfaction. Empirical analysis shows that the website design and reliability, product variety and delivery timeliness have significant effect on the net purchase satisfaction, while the time saving has no significant effect on net purchase satisfaction [14]. Maktoba Omar and Ian Bathgate (2011) discusses the impact factors of China's online shopping customer satisfaction, and points out the potential impact factors are the convenience, product performance, customer service, security, website interactivity and web site can be appreciated [5]. Cho and Park established the network shopping satisfaction scale, in this scale, the determinants of online shopping satisfaction includes provides product information, customer service, the results and service delivery, website design, the delivery of time and price, payment methods, the use of simple degree, the process, product planning and provide additional information services [15].

In recent years, domestic scholars have made some research on the satisfaction of consumer shopping satisfaction. Yang Hongfen analysis the consumer satisfaction factors from the web information authenticity, transaction security, shopping convenience and product quality and other aspects [16]. Wang Lisheng and Cha Jinxiang (2006), based on the theory of expectation and service quality measurement, constructed a structure model of the relationship between service quality, customer expectation and customer satisfaction [17].

At present, in the related literature at home and abroad, the research on the satisfaction of the college students' 
satisfaction degree in the Shopping Festival is less and broad, and there is a lack of satisfaction research on College Students' online shopping satisfaction in special holiday carnival. Therefore, this article through the questionnaire to analysis the influence factors of college students online shopping satisfaction in the shopping Carnival festival, establish the index evaluation system and model of satisfaction degree to improve the satisfaction of college students after carnival.

\section{The Evaluation Index System}

In order to cater to the young people's creative mentality, network building festival is attached to a unique network culture system, using the advantage of Internet which is break geographical and time limit, and at present, it set off a non-traditional festival holiday spree. The data shows that our country college students put more experience in the Shopping Festival and others characteristic festival. Double eleven "singles day" is the most popular. The "singles day" is made up of four same " 1 " which is very image. Therefore, the "singles day" is named by it's date and like four sticks. Other similar network Festival is the "girl day" "Double Twelve" etc.

The research of this paper is based on the evaluation system of the customer satisfaction degree on Taobao, which is built by Shi X.D. et al. [18]. According the actual situation of College Students' online shopping behavior and the practical problems of online shopping during the "Shopping Festival", the paper established the evaluation index system of College Students' participation in the later satisfaction degree of shopping carnival. Evaluation system is divided into the following three indicators: First class indicator is total evaluation objectives, which is Online shopping satisfaction of college students after the Shopping Festival; Second class indicator including 6 indicators, such as online shopping security, logistics, distribution systems and so on; third class indicator is derived by 18 specific measurement variables. The specific variables see the Table 1.

Table 1. Satisfaction measurement system of college students online shopping.

\begin{tabular}{|c|c|c|}
\hline First class indicator & Second class indicator & Third class indicator \\
\hline & & The price is moderate and the cost-effective \\
\hline & Online shopping product value advantage & The consistent degree of products and website propaganda \\
\hline & (VA) & The seller can meet the requirements of customers \\
\hline & & The consistent degree of Physical products and expectation \\
\hline & & Personal privacy \\
\hline & Online shopping security (0S) & Online payment security \\
\hline & & the reliability of online shop \\
\hline & & Timeliness of delivery \\
\hline \multirow{10}{*}{$\begin{array}{l}\text { Online shopping } \\
\text { satisfaction of college } \\
\text { students after the } \\
\text { Shopping Festival } \\
\text { (CSI) }\end{array}$} & Logistics and distribution systems (LS) & The speed of the delivery of goods \\
\hline & & Service attitude of delivery personnel \\
\hline & & The rating and evaluation \\
\hline & Virtual community interaction (CI) & The system recommended \\
\hline & & Effective communication with the merchant \\
\hline & & Timeliness and quality of return service \\
\hline & Sales and after-sales service (SS) & The convenience of after-sales service system \\
\hline & & Channels for the customer to reflect the views of the business \\
\hline & & Loyalty to online shopping \\
\hline & Customer expectation (CE) & Look forward to the next online shopping promotions \\
\hline
\end{tabular}




\section{The Empirical Research}

\subsection{The Empirical Purpose and Data Collection}

In the empirical study of this article, according to the theory of customer satisfaction and the data gathered, our investigation focus on the latter part of the online shopping satisfaction under the situation of Shopping Festival.

With the purpose of the research, the problem is set up and the corresponding variables are as follows: Table 2.

We use professional platform for the online questionnaire, which is SOJUMP.com. The object of our study is the university students and graduate students in Shaanxi province. After recycling questionnaire, through standard screening process to remove obvious logical error data, we get 789 valid questionnaires. Using SPSS 20 statistical software, the overall reliability coefficient $\alpha$ is 0.931, as follows: Table $\mathbf{3}$, which showed that the questionnaire had high reliability.

\subsection{The Factor Analysis of Customer Satisfaction and Its Influencing Factors}

Using SPSS 20.0, the collected data are dealt with dimension reduction analysis. According to the test of KMO and Bartlett, we can see in Table 4, the Bartlett test value is 0.000 , the KMO value is 0.890, so the sample is very suitable for the factor analysis.

Table 2. The measurement variables of satisfaction.

\begin{tabular}{|c|c|c|}
\hline Core indicator & Variable description & Test number \\
\hline \multirow{4}{*}{$\begin{array}{l}\text { Online shopping product } \\
\text { value advantage (VA) }\end{array}$} & The price is moderate and the cost-effective & Test 17 \\
\hline & The consistent degree of products and website propaganda & Test 4 \\
\hline & The seller can meet the requirements of customers & Test 6 \\
\hline & The consistent degree of Physical products and expectation & Test 5 \\
\hline \multirow{3}{*}{ Online shopping security (0S) } & Personal privacy & Test 7 \\
\hline & Online payment security & Test 9 \\
\hline & the reliability of online shop & Test 8 \\
\hline \multirow{3}{*}{$\begin{array}{l}\text { Logistics and distribution } \\
\text { systems (LS) }\end{array}$} & Timeliness of delivery & Test 14 \\
\hline & The speed of the delivery of goods & Test 13 \\
\hline & Service attitude of delivery personnel & Test 15 \\
\hline \multirow{3}{*}{$\begin{array}{l}\text { Virtual community } \\
\text { interaction (CI) }\end{array}$} & The rating and evaluation & Test 18 \\
\hline & The system recommended & Test 19 \\
\hline & Effective communication with the merchant & Test 11 \\
\hline \multirow{5}{*}{$\begin{array}{l}\text { Sales and after-sales service } \\
\text { (SS) }\end{array}$} & Timeliness and quality of return service & Test 12 \\
\hline & The convenience of after-sales service system & Test 10 \\
\hline & Channels for the customer to reflect the views of the business & Test 16 \\
\hline & Loyalty to online shopping & Test 20 \\
\hline & Look forward to the next online shopping promotions & Test 21 \\
\hline
\end{tabular}

Table 3. Reliability statistics.

\begin{tabular}{ccc}
\hline Cronbach's Alpha & Cronbach’s Alpha Based on Standardized Items & N of Items \\
\hline .931 & 0.934 & 18 \\
\hline
\end{tabular}

Table 4. KMO and Bartlett's test.

\begin{tabular}{ccc}
\hline \multicolumn{2}{c}{ Kaiser-Meyer-0lkin Measure of Sampling Adequacy } & 0.890 \\
\hline Bartlett's Test of & Approx. Chi-Square & 1049.008 \\
Sphericity & df & 36 \\
& Sig & 0.000 \\
\hline
\end{tabular}


We extracted 6 common factors from the surface of the rock (Figure 1) and the total variance (Table 5).

We can determine the observed variables for each of the common factors through the Rotated Factor Matrix (Table 6). At the same time, according to the contents of the high load observation variables in each factor, named for each of the common factors. The results of the study are as follows:

- The first common factors is logistics and distribution systems(LS), its observational variable are the timeliness of delivery, the speed of the delivery of goods and service attitude of delivery personnel;

- The second common factors is online shopping product value advantage (VA), its observational variable are the price is moderate and the cost-effective, the consistent degree of products and website propaganda ,the seller can meet the requirements of customers and the consistent degree of Physical products and expectation.

- The third common factors is customer expectation(CE), its observational variable are loyalty to online shopping and look forward to the next online shopping promotions.

- The fourth common factors is online shopping security (OS), its observational variable are personal privacy, online payment security and the reliability of online shop.

- The fifth common factors is sales and after-sales service (SS), its observational variable are effective communication with the merchant, timeliness and quality of return service, the convenience of after-sales service system and channels for the customer to reflect the views of the business

- The sixth common factors is virtual community interaction (CI), its observational variable are the rating and evaluation and the system recommended.

The reliability coefficient of each common factor is more than 0.7 , so the internal consistency of the factors is good, but the total alpha reliability coefficient is more than 0.9 , which shows that the sample has good reliability and high internal consistency.

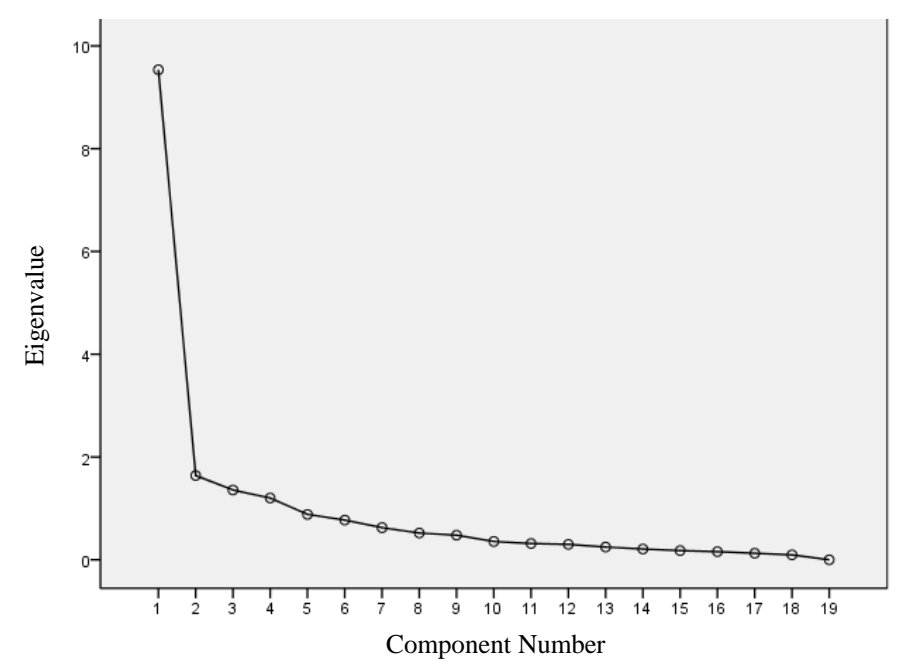

Figure 1. Scree plot.

Table 5. Total variance explained.

\begin{tabular}{cccccccccc}
\hline \multirow{2}{*}{ Component } & \multicolumn{3}{c}{ Initial Eigenvalues } & \multicolumn{3}{c}{ Extraction Sums of Squared Loadings } & \multicolumn{2}{c}{ Rotating Sums of Squared Loadings } \\
\cline { 2 - 10 } & Total & \% of Variance & Cumulative \% & Total & \% of Variance & Cumulative \% & Total & \% of Variance & Cumulative \% \\
\hline 1 & 9.535 & 50.186 & 50.186 & 9.535 & 50.186 & 50.186 & 3.331 & 17.530 & 17.530 \\
2 & 1.639 & 8.628 & 58.814 & 1.639 & 8.628 & 58.814 & 3.318 & 17.463 & 34.993 \\
3 & 1.358 & 7.147 & 65.961 & 1.358 & 7.147 & 65.961 & 2.932 & 15.433 & 50.426 \\
4 & 1.202 & 6.325 & 72.286 & 1.202 & 6.325 & 72.286 & 2.299 & 12.102 & 62.528 \\
5 & 0.883 & 4.647 & 76.933 & 0.883 & 4.647 & 76.933 & 2.231 & 11.740 & 74.269 \\
6 & 0.772 & 4.062 & 80.995 & 0.772 & 4.062 & 80.995 & 1.278 & 6.727 & 80.995 \\
\hline
\end{tabular}




\subsection{The Regression Analysis of Customer Satisfaction and Its Influencing Factors}

Six common factors which are get from regression analysis as the independent variable, and customer satisfaction as a dependent variable for stepwise regression analysis. Table 7 shows that, from the point of coefficient significance test, three model coefficients are significant, and the model 3's goodness-of-fit of the best is better, so, we choose the model 3.

The t test of three factors, Online shopping product value advantage (VA), Logistics and distribution systems (LS), Sales and after-sales service (SS),are significantly $(\mathrm{P}<0.10)$, but the Online shopping securit (0S), Virtual community interaction (CI), Customer expectation (CE) did not pass the test, so they have been removed. We can get the customer satisfaction regression equation, just as follow:

$$
\mathrm{CSI}=0.409+0.427 \times \mathrm{LS}+0.349 \times \mathrm{SS}+0.204 \times \mathrm{VA} .
$$

Table 6. Rotated factor matrix.

\begin{tabular}{|c|c|c|c|c|c|c|}
\hline \multicolumn{7}{|c|}{ Rotated Factor Matrix } \\
\hline & \multicolumn{6}{|c|}{ Component } \\
\hline & 1 & 2 & 3 & 4 & 5 & 6 \\
\hline Test 4 & . & 0.813 & & & & \\
\hline Test 5 & & 0.808 & & & & \\
\hline Test 6 & & 0.813 & & & & \\
\hline Test 7 & & & & 0.896 & & \\
\hline Test 8 & & & & 0.532 & & \\
\hline Test 9 & & & & 0.769 & & \\
\hline Test 10 & & & & & 0.620 & \\
\hline Test 11 & & & & & & 0.677 \\
\hline Test 12 & & & & & 0.739 & \\
\hline Test 13 & 0.727 & & & & & \\
\hline Test 14 & 0.809 & & & & & \\
\hline Test 15 & & & & & & \\
\hline Test 16 & & & & & 0.792 & \\
\hline Test 17 & & 0.547 & & & & \\
\hline Test 18 & & & & & & 0.843 \\
\hline Test 19 & & & & & & 0.787 \\
\hline Test 20 & & & 0.786 & & & \\
\hline Test 21 & & & 0.834 & & & \\
\hline
\end{tabular}

Table 7. The result of customer satisfaction's regression analysis.

\begin{tabular}{cccc}
\hline & \multicolumn{2}{c}{ CSI } & Model 3 \\
\hline Explanatory Variable & Model 1 & Model 2 & 0.409 \\
Constant & 0.612 & 0.438 & $0.427^{* *}$ \\
LS & $0.763^{* *}$ & $0.584^{* *}$ & $0.349^{* *}$ \\
SS & & $0.401^{* *}$ & $0.204^{* *}$ \\
VA & & & 0.472 \\
R2 & 0.349 & 0.437 & 70.673 \\
F & 122.784 & 87.369 & \\
\hline
\end{tabular}

$\mathrm{N}=80 ;{ }^{* *} \mathrm{P}<0.01$. 


\section{The Model of the Satisfaction}

Through the factor analysis, the writer found out several independent and representative factors, which influence the college students' online shopping satisfaction after the Shopping Festival. The modified index system for the following Table 8.

The modified evaluation index system of later satisfaction degree, which is the College Students' participation in shopping carnival, is 1 first class indicator-Customer satisfaction, 3 second class indicator-Online shopping product value advantage (VA), Logistics and distribution systems (LS), Sales and after-sales service (SS), 10 third class indicator, Now we will explain the following specific indicators (Table 9).

After continuous correction, we can eventually get the college students online shopping late satisfaction model under the network building festival situation, as Figure 2.

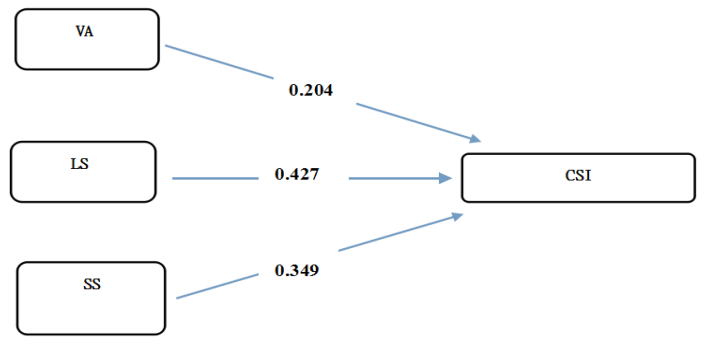

Figure 2. The model of the satisfaction after the Shopping Festival.

Table 8. The model of the satisfaction after the Shopping Festival.

\begin{tabular}{|c|c|c|}
\hline First class indicator & Second class indicator & Third class indicator \\
\hline \multirow{10}{*}{$\begin{array}{l}\text { Online shopping satisfaction } \\
\text { of college students after the } \\
\text { Shopping Festival (CSI) }\end{array}$} & \multirow{4}{*}{$\begin{array}{l}\text { Online shopping product value } \\
\text { advantage (VA) }\end{array}$} & The price is moderate and the cost-effective \\
\hline & & The consistent degree of products and website propaganda \\
\hline & & The seller can meet the requirements of customers \\
\hline & & The consistent degree of Physical products and expectation \\
\hline & \multirow{3}{*}{$\begin{array}{l}\text { Logistics and distribution } \\
\text { systems (LS) }\end{array}$} & Timeliness of delivery \\
\hline & & The speed of the delivery of goods \\
\hline & & Service attitude of delivery personnel \\
\hline & \multirow{3}{*}{ Sales and after-sales service (SS) } & Timeliness and quality of return service \\
\hline & & The convenience of after-sales service system \\
\hline & & Channels for the customer to reflect the views of the business \\
\hline
\end{tabular}

Table 9. The explanation of the model of satisfaction degree.

\begin{tabular}{|c|c|}
\hline Indicator & Explanation \\
\hline $\begin{array}{l}\text { Online shopping product } \\
\text { value advantage (VA) }\end{array}$ & $\begin{array}{l}\text { Whether shopping in the shopping festival, the core of customer satisfaction is always the value of the } \\
\text { product-Online shopping itself brings consumer experience As well as products that meet consumer } \\
\text { expectations. So we attribute the customer expectations and virtual community interaction to this indicator. }\end{array}$ \\
\hline $\begin{array}{l}\text { Logistics and distribution } \\
\text { systems (LS) }\end{array}$ & $\begin{array}{l}\text { the trading volume of shopping festival is huge, it need a strong logistics and distribution systems to } \\
\text { support., so the customer perceived benefit of logistics is the largest factor impact on satisfaction after } \\
\text { shopping. Delivery speed, logistics personnel attitude and so on become the key to affect the degree of } \\
\text { satisfaction. }\end{array}$ \\
\hline $\begin{array}{l}\text { Sales and after-sales } \\
\text { service (SS) }\end{array}$ & $\begin{array}{l}\text { This paper focuses on the factors affecting the degree of satisfaction in the latter, and not only the } \\
\text { satisfaction of received the product, but also the satisfaction.in the use process. Although during the } \\
\text { shopping festival, the volume is large, but the probability of the final failure of the transaction is also great. } \\
\text { This leads to a large number of negotiations between customers and businesses in the late. The process of } \\
\text { negotiations often affect customer satisfaction; On the other hand, if there is a problem of information } \\
\text { disclosure, property security and other issues, they will also affect the satisfaction of online shopping. }\end{array}$ \\
\hline
\end{tabular}




\section{Conclusion}

\subsection{Research Suggestion}

For all of the electricity supplier brands, "build festival" marketing is a new inspiration. Once consumers have become accustomed to the Chinese New Year, Valentine's Day, May Day, National Day and other traditional festivals, through the creation of new forms of holiday, explore and guide consumer demands, and it is extremely important to enhance customer value where the consumer is online shopping. Based on the phenomenon of network building festival, the paper's empirical research shows that the satisfaction is was significantly affected by the online shopping product value advantage, logistics and distribution systems and the sales and after-sales service. Based on those, we can put forward a series of strategies to improve customer satisfaction:

- Electricity suppliers: the use of new technologies to enhance the user experience, such as the location of the preferential information push, the goods are online verification, the comparison of physical stores and online stores in quality and price; After the Shopping Festival, each electricity suppliers can set up their own online shopping satisfaction survey to improve service quality.

- Support service system: Logistics and distribution should establish forecasting mechanism and the emergency plan for Shopping Festival. They should make strategic alliances with the electric business enterprise. Logistics enterprises can deal with the sale of goods; Logistics enterprises can also establish distribution alliance, through the realization of resource sharing to improve the express processing capacity.

- Country: Strengthen the introduction of the law and the regulation of virtual communities to ensure that the interests of customers are not damaged; Standard the after-sales service system, especially the electricity business service system.

\subsection{Innovations and Deficiencies}

The Innovations of this paper is stay in studying the satisfaction factors of the customer later shopping behavior in the situation of network made festival, these three factors such as the advantages of online shopping product value, sales and after-sales service, the systems of distribution that was creatively putted forward influenced the behavior of college students late shopping the implications, supplying the vacancy of a certain part of for this study, contributing to the improving the theory of consumer behavior. However, the study that focus on only college students in this paper, can not represent the whole population even if representing the characteristics of the individual groups, so furtherly expanding and developing the depth influence of the sample of post-consumer shopping behavior.

\section{References}

[1] Cardozo, R.N. (1965) An Experimental Study of Customer Effort, Expectation, and Satisfaction. Journal of Marketing Research (JMR), 2. http://dx.doi.org/10.2307/3150182

[2] Howard, J.A. and Sheth, J.N. (1969) The Theory of Buyer Behavior. Wiley Marketing.

[3] Hunt, H.K. (1977) Conceptualization and Measurement of Consumer Satisfaction and Dissatisfaction. Marketing Science Institute.

[4] Westbrook, R.A. (1980) Intrapersonal Affective Influences on Consumer Satisfaction with Products. Journal of Consumer Research. http://dx.doi.org/10.1086/208792

[5] Bian, W.-L., Song-Dong, J.U., Jie, X.U., et al. (2011) An Empirical Research on Online B2C Customer Perceptions of Logistics Services and Related Factors. Journal of Industrial Engineering \& Engineering Management.

[6] Zhao, Y.H. and Han, Z.J. (2007) A Model of Higher Education Customer Satisfaction by SEM. Systems Engineering, 25, 85-90.

[7] Hempel, D.J. (1977) Consumer Satisfaction with the Home Buying Process: Conceptualization and Measurement. The Conceptualization of Consumer Satisfaction and Dissatisfaction, 7.

[8] Harris, L.C. and Reynolds, K.L. (2003) The Consequences of Dysfunctional Customer Behavior. Journal of Service Research, 6, 144-161. http://dx.doi.org/10.1177/1094670503257044

[9] Ikegame, M. (1979) Conceptualization and Measurement of Consumer Satisfaction and Dissatisfaction. Otemon Economic Studies, 12.

[10] Kim, S.Y. and Lim, Y.J. (2001) Consumers’ Perceived Importance of and Satisfaction with Internet Shopping. Electronic Markets, 11, 148-154. http://dx.doi.org/10.1080/101967801681007988 
[11] Bai, B., Law, R. and Wen, I. (2008) The Importance of Website Quality on Customer Satisfaction and Purchase Intentions: EvCIence from Chinese Online Visitors. International Journal of Hospitality Management, 27, 391-402. http://dx.doi.org/10.1016/j.ijhm.2007.10.008

[12] Alam, S.S. and Yasin, N.M. (2010) An Investigation into the Antecedents of Customer Satisfaction of Online Shopping. Journal of Marketing Development \& Competitiveness, 5, 71-78.

[13] Omar, M., Bathgate, I. and Nwankwo, S. (2011) Nwankwo. Internet Marketing and Customer Satisfaction in Emerging Markets: The Case of Chinese Online Shoppers. 21, 224-237.

[14] Cho, N. and Park, S. (2001) Development of Electronic Commerce User-Consumer Satisfaction Index (ECUSI) for Internet Shopping. Industrial Management and Data Systems, 101, 400-405. http://dx.doi.org/10.1108/EUM0000000006170

[15] Chu, C.W. and Lu, H.P. (2007) Factors Influencing Online Music Purchase Intention in Taiwan: An Empirical Study Based on the Value-Intention Framework. Internet Research Electronic Networking Applications \& Policy, 17, 139-155(17).

[16] Zha, J. and Wang, L. (2006) Empirical Study of Influential Elements of E-Satisfaction. Science of Management, 19, 52-57.

[17] Tian, J. (2011) An Empirical Study on the Relations between E-Service Quality and Online Shopping Satisfaction of College Students. Journal of Nanjing University of Posts \& Telecommunications.

[18] Shi, X.D. (2013) Research on Customer Satisfaction of Online Shopping on Taobao. Standard Science. 